\title{
Reinforcement of renovated slope against additional steeper cutting at the lower part
}

\author{
Chan-Kee Jung ${ }^{1 *}$ (D) and Sang-Duk Lee ${ }^{2}$
}

*Correspondence:
chankee@kccworld.net
${ }^{1}$ Dept. of Civil \&Trans.
Sys. Eng., Ajou Univ., 206
Wouldcup-ro, Youngtong-gu,
Suwon-si, Gyounggi-do
16499, South Korea
Full list of author information
is available at the end of the
article

*Correspondence: chankee@kccworld.net Sys. Eng. Ajou Univ., 206 Wouldcup-ro, Youngtong-gu, Suwon-si, Gyounggi-do article

\begin{abstract}
The behavior of a slope reinforced by passive piles 15 years ago was studied during removal of some passive piles, additional steeper slope cutting, and reinforcement by soil nails and anchors. Through a comparison of the measured value and numerical analysis results, it was found that the maximum lateral displacement developed at bench No. 4, which was the nearest bench to the additional steep slope cutting, and it could be correlated with the groundwater table. In particular, the relaxation of the ground from past failure sliding could affect the slope stability.
\end{abstract}

Keywords: Passive piles, Soil nails, Ground anchors, Behavior of renovated slopes, Ground water table, Numerical analysis

\section{Introduction}

For the development of urban areas and traffic solutions, more steep slopes and cuttings are being constructed, and significant land sliding and collapse of slopes has been reported recently during the widening of existing road sites [1,2].

The slope in this study was cut for road construction, but, after the first construction, it experienced a large-scale landslide with tension cracks. It was reinforced by five rows of passive piles to halt the slope sliding. It has been maintained safely for 15 years [3].

However, additional steeper slope cutting was planned to widen the road, and the lower three rows out of the five rows of passive piles needed to be removed. Additional reinforcement with soil nails and concrete panel walls with ground anchors was planned [4].

To verify the reinforcement effect of the existing passive piles and additional soil-nails and concrete panels with ground anchors, the behavior of a new steeper slope was measured in site and analyzed numerically to determine the slope's behavior.

In this study, the stress and displacement of a slope at every construction stages (cutting and reinforcement) were verified by comparing the measured results at the existing passive piles with the results of numerical analyses [5]. 


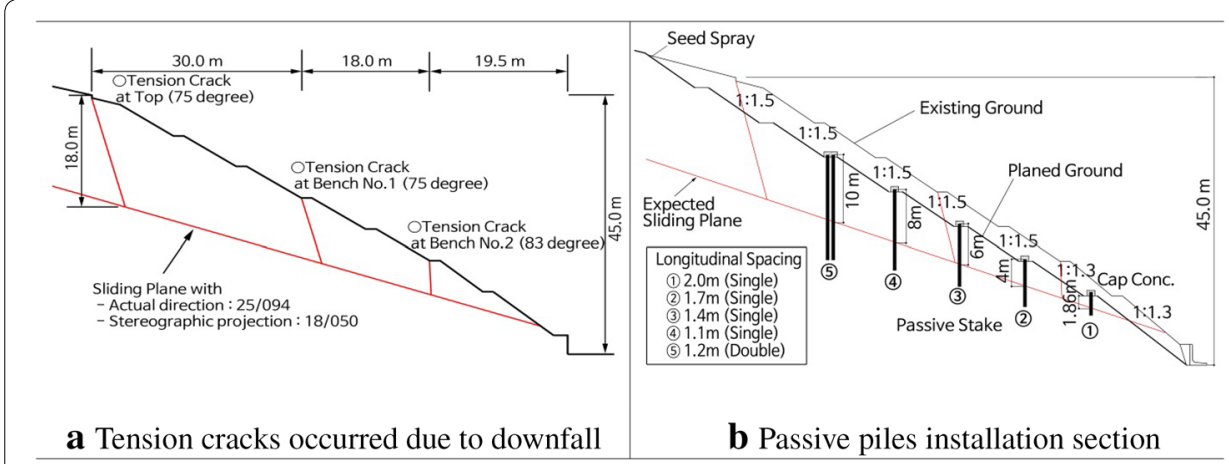

Fig. 1 Existing section with passive piles

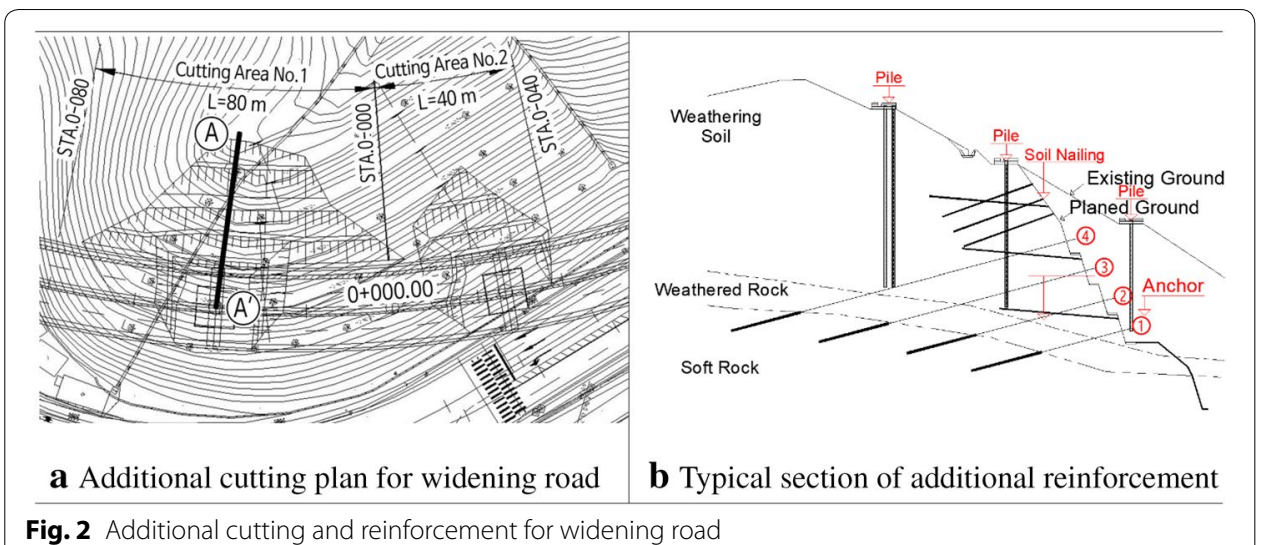

\section{Field status}

Profile

Referring to Fig. 1a and b, the slope was located at the Singal-Suji road in Gyeonggido, South Korea. It had a height of $45 \mathrm{~m}$ height and longitudinal length of $380 \mathrm{~m}$.

As shown in the figures, it experienced a wedge-shaped land sliding of the blocks with $40 \mathrm{~m}$ height and $380 \mathrm{~m}$ longitudinal length in August 2002. Vertical cracks of $18 \mathrm{~m}$ depth were measured at the slope crest.

In 2003, as shown in Fig. 1b, passive piles with $250 \mathrm{~mm}$ diameter casing and $150 \times 150 \times 7 \times 10 \mathrm{~mm} \mathrm{H}$-shaped piles with cement mortar filling were installed on benches Nos. 1-5 (All piles were capped with concrete, and a double-row was installed on bench No. 5).

The slope needs to be cut at a steeper angle to widen the road. For this work, the lower three rows of passive piles should be removed, and the more steeply cut slope should be reinforced by soil-nails at the upper part and by a concrete panel wall with a ground anchor at the lower part (see Fig. 2).

During the steeper slope cut, the lower three rows of passive piles on bench No. 3 to No. 1 were removed, and four stories of concrete panel wall with a ground anchor were built as shown in Fig. 3a and b (the upper steeper slope was reinforced by the concrete panel wall, in which three layers of soil nails were installed). 


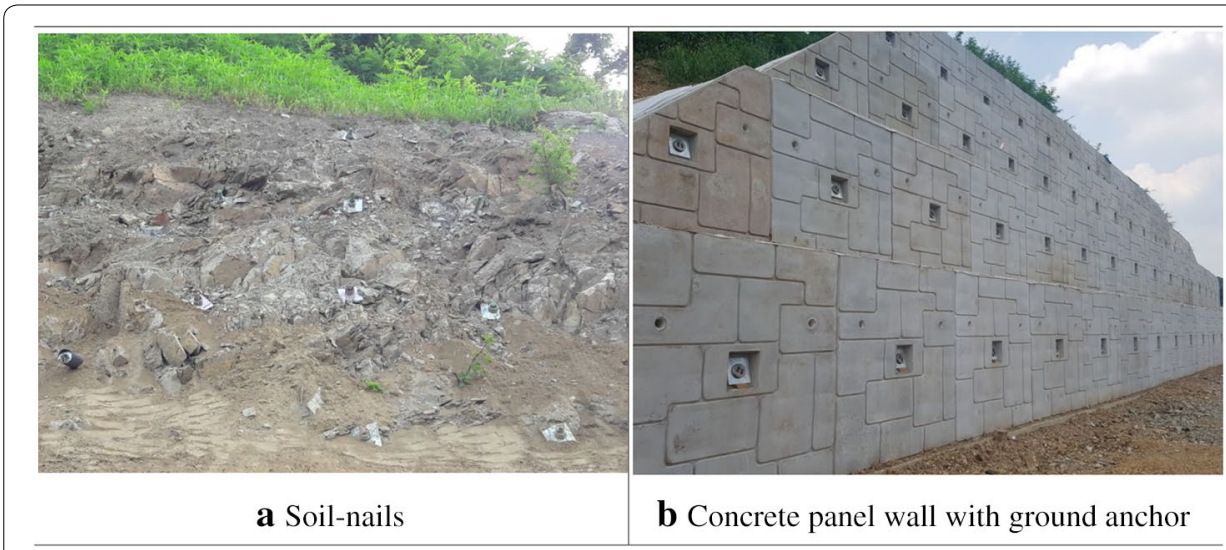

Fig. 3 Additional reinforcement for widening road

Table 1 Summary of ground properties (ground investigation report) [4]

\begin{tabular}{llllll}
\hline Layer & $\begin{array}{l}\text { Unit weight } \\
\left(\mathbf{k N} / \mathbf{m}^{\mathbf{3}}\right)\end{array}$ & Cohesion $\mathbf{( \mathbf { k P a } )}$ & $\begin{array}{l}\text { Internal } \\
\text { friction angle } \\
\left.\mathbf{(}^{\circ}\right)\end{array}$ & $\begin{array}{l}\text { Deformation } \\
\text { modulus (MPa) }\end{array}$ & Poisson's ratio \\
\hline Deposit soil & 19 & - & 30 & 33 & 0.35 \\
Weathered soil & 19 & 25 & 28 & 40 & 0.32 \\
Weathered rocks & 20 & 35 & 33 & 200 & 0.30 \\
Bed rocks & 20 & 200 & 35 & 1000 & 0.28 \\
\hline
\end{tabular}

\section{Geological history and underground condition}

The ground in the site consists of deposit soil, weathered soil, weathered rocks, and bed rocks from the ground surface.

- The deposit soil is composed of sandy gravel with silt for a depth of $1 \mathrm{~m}$ from the surface.

- The weathered soil is composed of silty sand (and a little bit of rock fragment) with a depth of 1.5-13.6 m under the bottom of the deposit soil.

- The weathered rocks are located at a 1.0-11.4 m depth under the bottom of the weathered soil. Rock fragment core can be found in it.

- The bed rocks seems to be highly or moderately weathered with lots of joints and fragments. Test core recovery of the bed rocks reaches $22-75 \%$, and the rock quality designation reaches $0-12 \%$.

Table 1 shows the physical properties of each soil and rock layer.

The ground water tables were observed at a depth of 8.8-15.5 m under the surface; however, they might be estimated higher. The permeability of the weathered soil and weathered rocks was evaluated as $7.48 \times 10^{-4} \mathrm{~cm} / \mathrm{s}$ and $9.02 \times 10^{-5} \mathrm{~cm} / \mathrm{s}$, respectively, from the downfall test in the bore holes. 


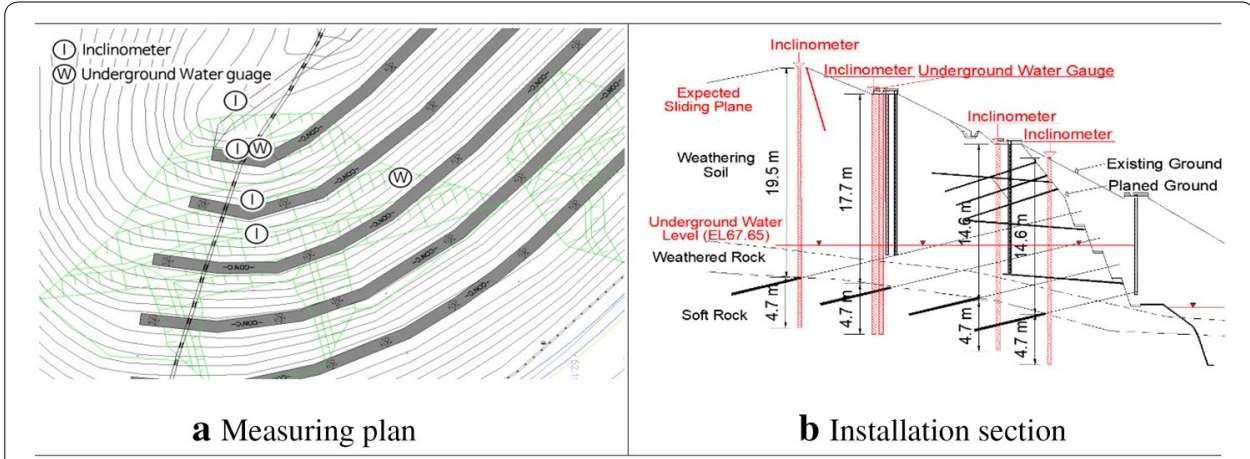

Fig. 4 Measuring plan of the typical section

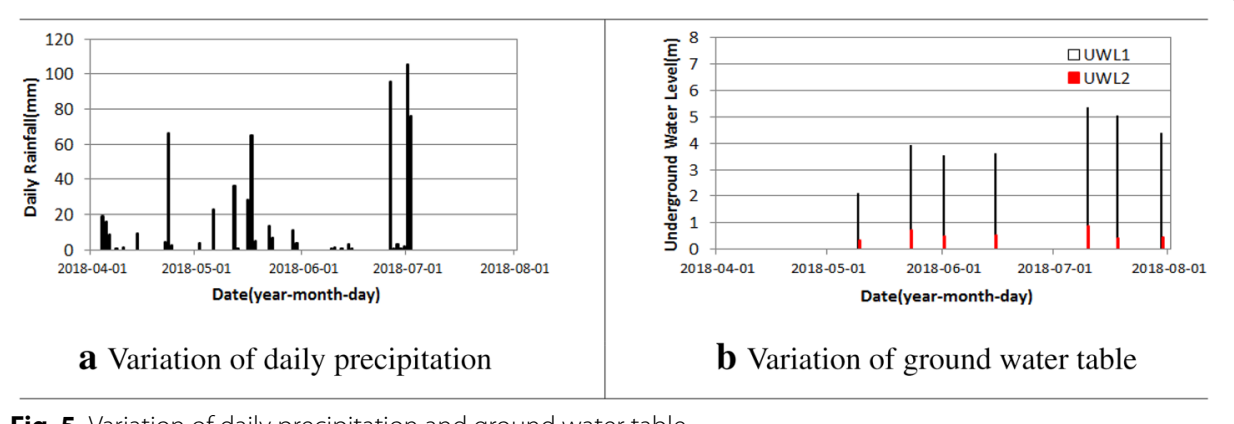

Fig. 5 Variation of daily precipitation and ground water table

\section{Measuring in site}

\section{Installation}

To measure the behavior of the existing passive piles induced by additional slope cutting and the steeper slope reinforcement, four inclinometers and two ground water gauges were installed at the location of the passive piles [6].

As shown in Fig. 4, inclinometers were installed adjacent to the piles at benches No. 5 and No. 4, and the soil-nails were installed from the surface to $5 \mathrm{~m}$ under the bed rock along the typical section. A ground water gauge was installed adjacent to the piles at bench No. 4 along the typical section. Figure 5 shows a photograph of installation and measuring on site.

\section{Results}

The variation of the ground water table in the weathered rocks during the steeper slope cutting and the reinforcement is shown in Fig. 5, which is highly dependent on precipitation [7-9]. The maximum increase of the ground water table was $5.33 \mathrm{~m}$.

No significant lateral displacement of the ground was observed at the crest of the slope. The maximum lateral displacements in weathered soil and rocks were $2.92 \mathrm{~mm}$ and $11.73 \mathrm{~mm}$, respectively. The total lateral displacements at the inclinometers at benches No. 5 and No. 4 areas are shown in Fig. 6. 


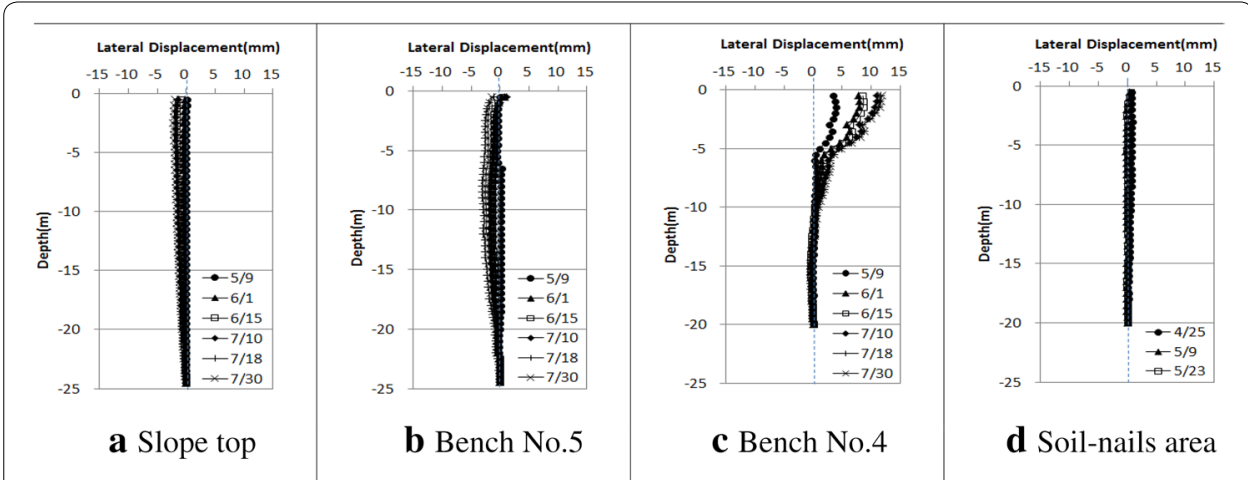

Fig. 6 Lateral displacement on the inclino-meters

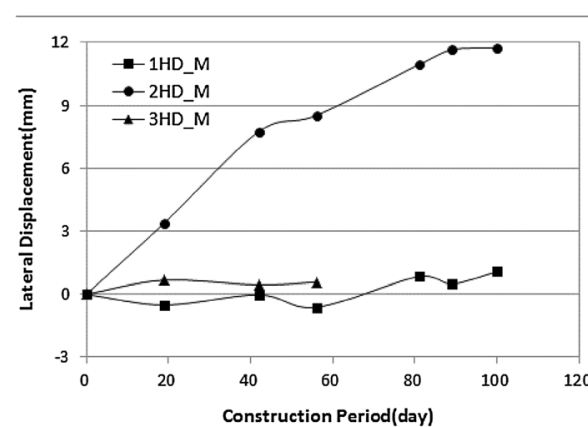

a Lateral displacement

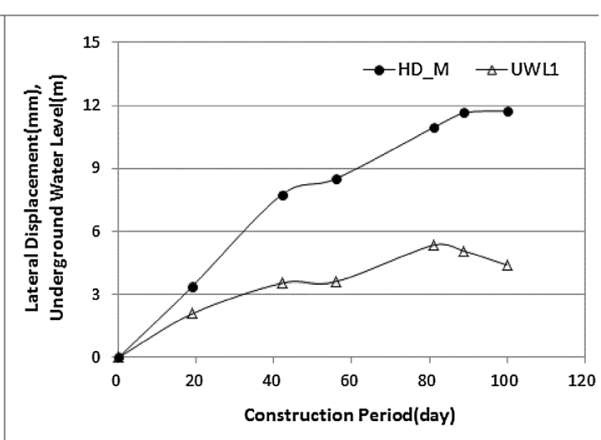

b Maximum lateral displacement with ground water tables

Fig. 7 Analysis of lateral displacement

The maximum lateral displacements of bench No. 5 and the soil-nailed area were $(-) 3.03 \mathrm{~mm}$ and $0.80 \mathrm{~mm}$, respectively, at depths of $8.0 \mathrm{~m}$ and $3.0 \mathrm{~m}$ from the surface.

However, the maximum lateral displacement of bench No. 4 was $11.73 \mathrm{~mm}$ at a depth of $0.5 \mathrm{~m}$ from the surface, which showed that passive piles at bench No. 4 deformed because of the steeper slope cutting.

\section{Analysis of results}

Lateral displacement at the ground surface and the maximum lateral displacement related to the ground water tables during the construction are shown in Fig. 7.

Figure $7 \mathrm{a}$ shows lateral displacement at the ground surface. As shown in the figure, no significant variation of lateral displacement at bench No. 5 (1HD_M) and the soil-nailing area (3HD_M) was observed during the slope cutting and rainfall. However, lateral displacement of the ground surface at the passive pile on bench No. 4 (2HD_M) increased gradually during the steeper slope cutting. Especially, the maximum lateral displacement of the passive piles of bench No. 4 (HD_M) and the ground water table near (UWL1) had a direct correlation.

All construction stages (steeper cutting and reinforcement in top-down method) can be designated as six stages as follows: 
- Installing soil-nails for steeper cutting (SN).

- Installing ground anchor for fourth-story concrete panel wall (4LA).

- Installing ground anchor for third-story concrete panel wall (3LA).

- Installing ground anchor for second-story concrete panel wall (2LA).

- Installing ground anchor for first-story concrete panel wall (1LA).

- Final ground excavation for the new bridge foundation (FE).

At the construction of stage $4 \mathrm{LA}, 66 \%$ of the total displacement was developed as shown in Fig. 8a. Figure 8b shows the difference of lateral displacement between the passive piles at benches No. 5 and No. 4 , which reached the maximum value at stage $1 \mathrm{LA}$.

\section{Numerical analysis}

\section{Modeling}

As shown in Fig. 9, numerical analysis was performed using MIDAS GTS (Developer: Midas Information Technology Co., Ltd., South Korea [10]) under consideration of the construction stages to verify the variation of displacements and stresses of the ground and the reinforcement members on each stage.

Physical and mechanical properties of soil layers and bed rock are shown in Table 2. Locations of soil and rock layers from the ground surface are shown below:

- Weathered soil 1: 0-6.0 m.

- Weathered soil 2: 6.0-12.0 m.

- Weathered rocks: $12.0-15.0 \mathrm{~m}$.

- Bed rocks: $15.0-20.0 \mathrm{~m}$.

The land sliding plane in 2002 was regarded as the interface between weathered soil layers 1 and 2 .

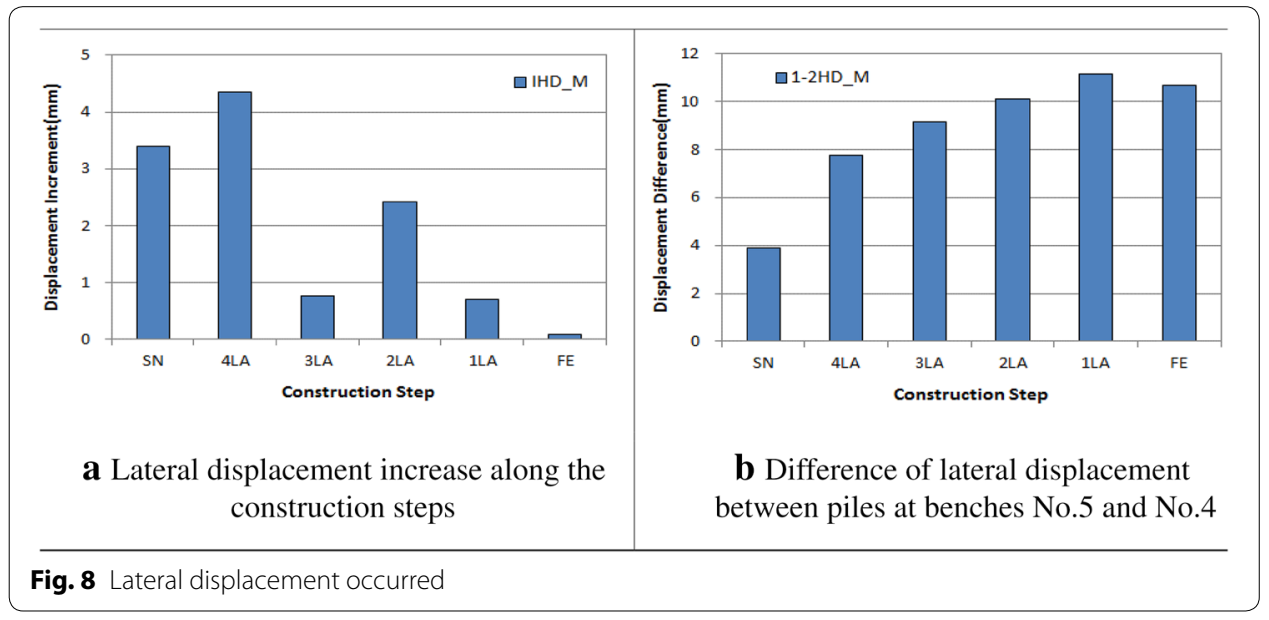




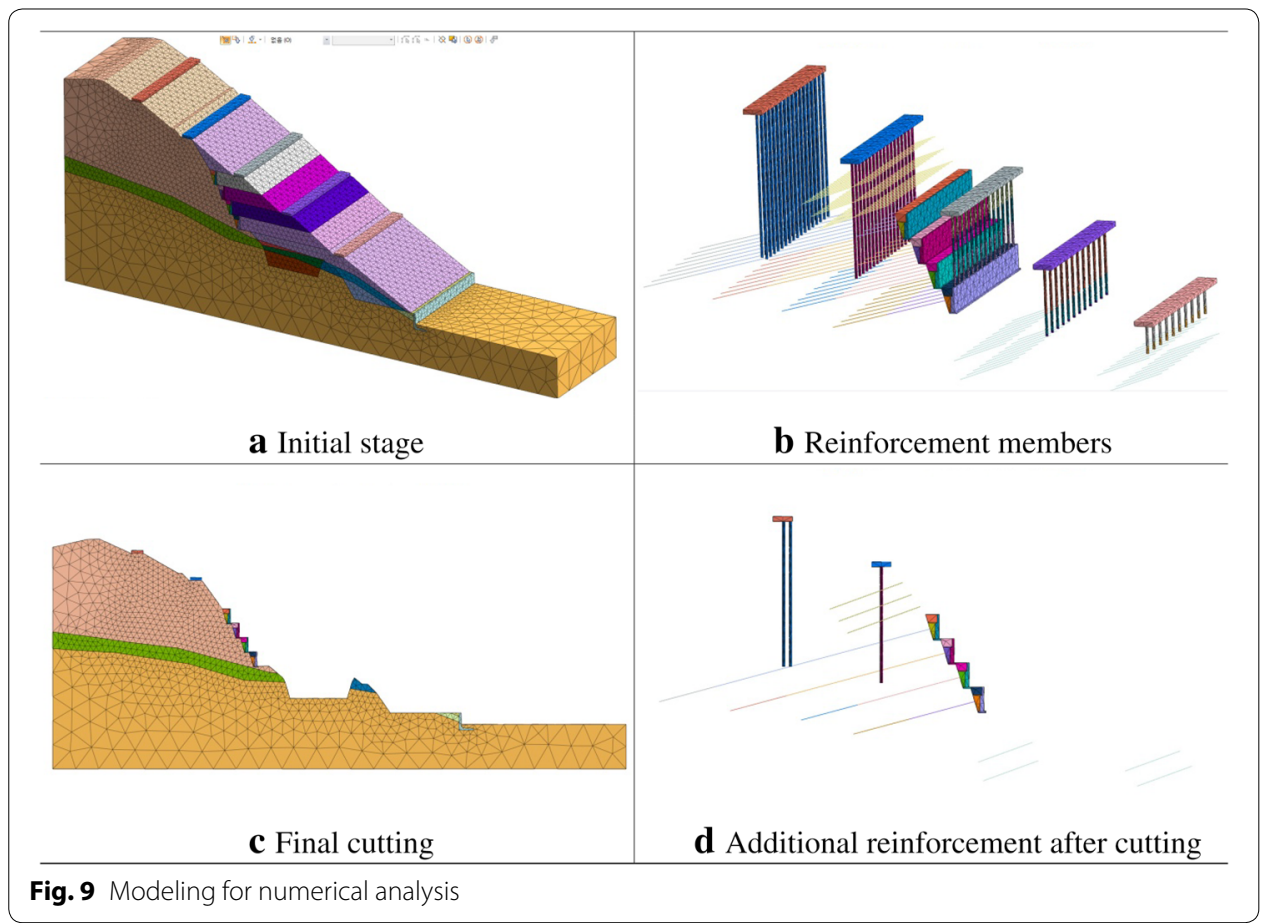

Table 2 Summary of input properties of soil and rock layers

\begin{tabular}{llllll}
\hline Layer & $\begin{array}{l}\text { Unit weight } \\
\left(\mathbf{k N} / \mathbf{m}^{\mathbf{3}}\right)\end{array}$ & Cohesion $\mathbf{( k P a )}$ & $\begin{array}{l}\text { Internal } \\
\text { friction angle } \\
\left({ }^{\circ}\right)\end{array}$ & $\begin{array}{l}\text { Deformation } \\
\text { modulus (MPa) }\end{array}$ & Poisson's ratio \\
\hline Weathered soil 1 & 19 & 15 & 30 & 14 & 0.35 \\
Weathered soil 2 & 19 & 25 & 28 & 40 & 0.32 \\
Weathered rock & 20 & 35 & 33 & 200 & 0.30 \\
Bed rock & 20 & 200 & 35 & 1000 & 0.28 \\
\hline
\end{tabular}

\section{Results of numerical analysis}

Figures 10 and 11 show the displacements and stresses during the construction in the whole slope. The maximum displacement and the maximum stress are observed at the top of the passive piles on bench No. 4 as shown in Fig. 12.

\section{Comparative analysis with measured value}

Comparative analysis of the numerical analysis results and measured values at the site are described below:

- No significant displacement was developed at the depth of the bed rocks and weathered rocks in the numerical analysis results and measured values at the site.

- The displacement of weathered soil layer 1 estimated numerically coincided with the measured value.

- The lateral displacement of weathered soil layer 2 estimated numerically was larger than the measured value at the site. 


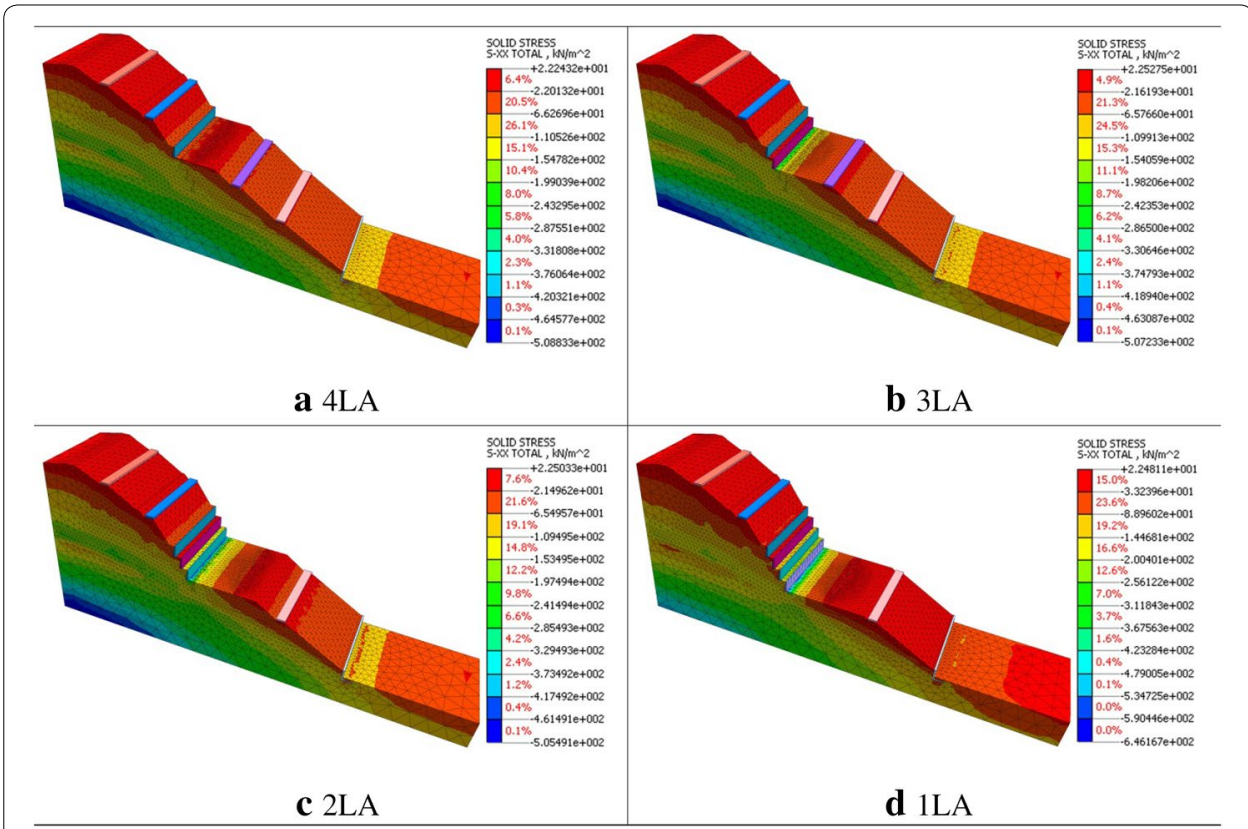

Fig. 10 Displacements that occurred to the whole slope during construction stages

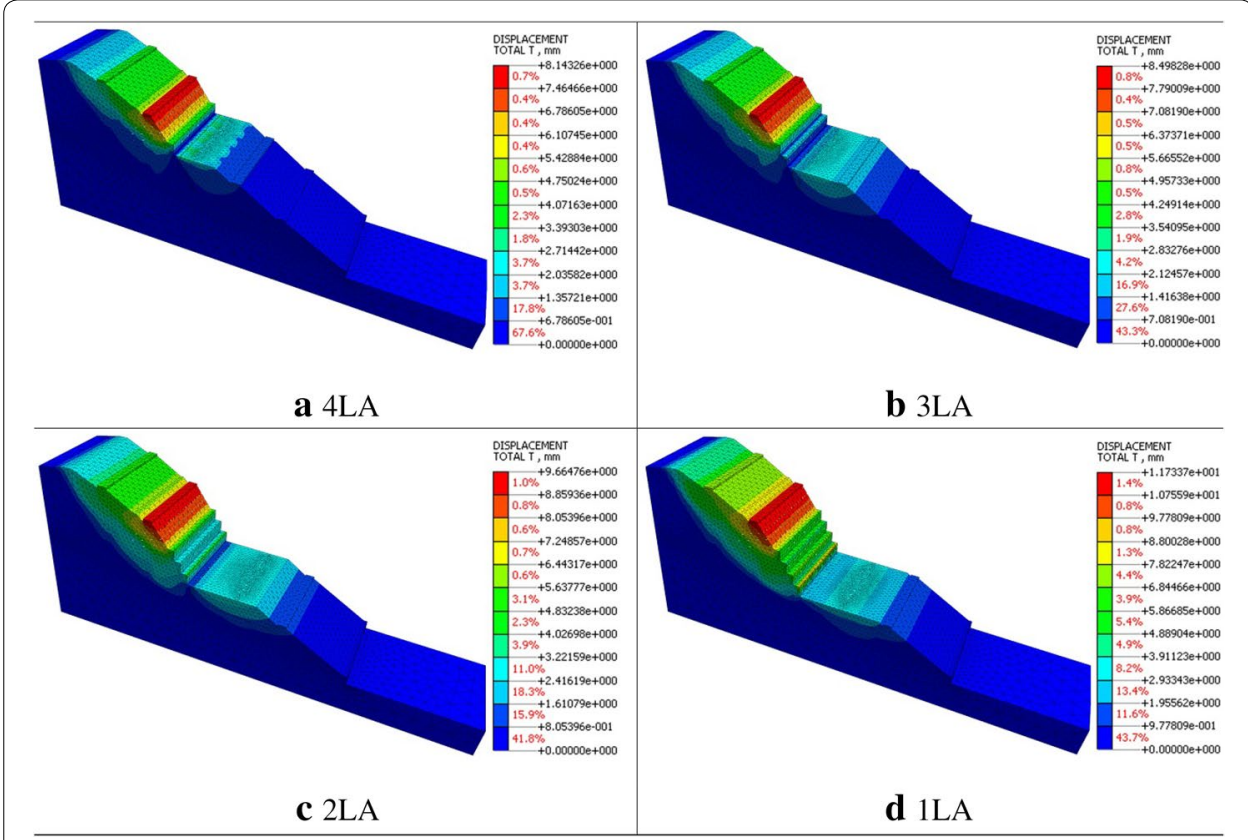

Fig. 11 Stresses that occurred to the whole slope during construction stages

- The lateral displacement on stages SN and 4LA estimated numerically coincided with the measured value at the site.

The numerically estimated lateral displacement at the ground surface of bench No. 4 was larger at anchor stages (4LA-2LA) and smaller at the SN and FE stages-see 


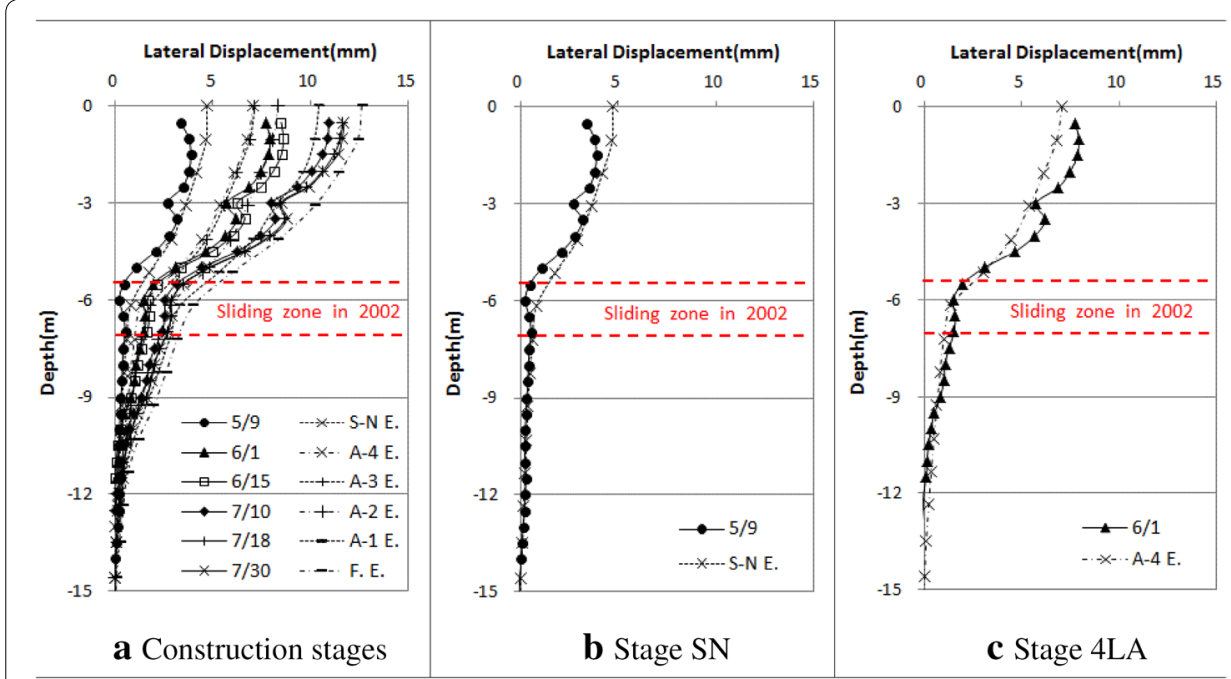

Fig. 12 Lateral displacement on bench No. 4 from numerical analysis and measuring

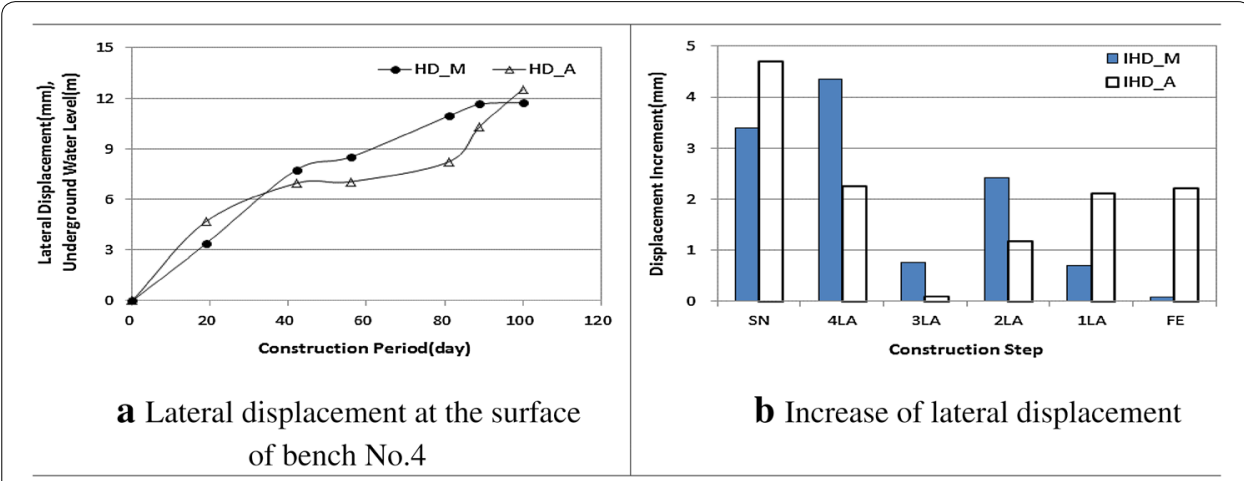

Fig. 13 Lateral displacement at the surface of bench No. 4 from numerical analysis and actual measurements

Fig. 13a. The lateral displacements estimated by the numerical analysis during the construction stages compared with the in-site measured value were as follows $[5,11$, $12]$.

- Larger than actual measured value at SN stage.

- Smaller than actual measured value since 2LA stage.

- Larger again after 1LA stage.

This seems to have happened because the numerical analysis model was varied more sensitively than the real ground by tensioning the ground anchors.

\section{Conclusion}

This study was performed to verify the effect of the reinforcement method for aslope renovated by five rows of passive piles 15 years ago. This slope had to be steepened for wider road construction. For steepening the slope, the lower three rows of the passive piles were 
removed, and the steepened slope was reinforced by soil-nails and four stories of concrete panel walls.

- The maximum lateral displacement was observed at the passive pile on bench No. 4, which reached $11.73 \mathrm{~mm}$ at the final steepening stage.

- The maximum increase of the ground water table in the weathered rocks during the steepening and reinforcement of the slope was $5.33 \mathrm{~m}$. The variation of the ground water table had a great effect on the displacement of the slope.

- The maximum lateral displacement developed in the slope-steepening stage for the fourth-story concrete panel wall (the first concrete panel wall from top-down cutting). There was $66 \%$ of total displacement in this stage, and, after this stage, the tension forces of the ground anchors could retrain the displacement.

- No significant displacement developed in the bed rocks and weathered rocks. However, in the weathered soil layer, a sharp increase of lateral displacement was observed during the construction stages, which shows that the past land sliding or failure plane could be redeemable and affect the stability of a slope.

- The lateral displacement by numerical analysis was estimated smaller than the actual value in the ground-anchoring stages. This means that the numerical analysis model reacts more sensitively than the real soil by tensioning ground anchors.

- The failure plane of a slope renovated by passive piles could be redeemed through steeper slope cutting. However, it could be stopped by soil-nails.

\section{Authors' contributions}

C-KJ carried out studies regarding the reinforcement of renovated slope, participated in the sequence alignment and drafted the manuscript. S-DL reviewed the draft prepared, presented directions and participated in final preparation. Both authors read and approved the final manuscript.

\section{Author details}

'Dept. of Civil \& Trans. Sys. Eng., Ajou Univ., 206 Wouldcup-ro, Youngtong-gu, Suwon-si, Gyounggi-do 16499, South Korea. ${ }^{2}$ Dept. of Civil Sys. Eng., Ajou Univ., Suwon, South Korea.

\section{Competing interests}

The authors declare that they have no competing interests.

\section{Publisher's Note}

Springer Nature remains neutral with regard to jurisdictional claims in published maps and institutional affiliations.

Received: 22 August 2018 Accepted: 1 November 2018

Published online: 16 November 2018

\section{References}

1. Hong WP, Han JG, Song YS, Shin DS (2003) Reinforcement effect of stabilizing piles in large-scale cut slope. In: KGS national conference, committee of slope stability, Seoul, Korea, pp 65-81

2. Song YS, Hong WP (2008) Proposal of a design method of slope reinforced by the earth retention system. J Eng Geol 18(1):17-26

3. Yong-In city (2002) Analysis report of large-scale cut slope at Singal plan-road project. Yong-In city, Gyunggi-do

4. Yong-In city (2017) Underground investigation report at start area II of Singal-Suji road widening project. Yong-In city, Gyunggi-do

5. Lee SD (2006) Erosion of slope due to the rainfall. In: Korean geotechnical society fall national conference, Daegu, Korea, October 27, pp 640-646

6. Yong-In city (2018) Measuring report of large-scale cut slope at start area II of Singal-Suji road widening project. Gyunggi-do, Korea

7. Hwang JA, Lee SD, Jeon MG, Koo JK (1993) A constrained simplex method for slope stability analysis. J Korean Soc Civil Engineers 13(4):209-215

8. Kim JS, Lee SD, Lee SR (2001) An experimental study on reinforcing effects for soil structures reinforced by nail with an anchor shape. J Korean Geotech Soc 17(2):103-111 
9. Lee SD, Kwon OY, Choi YK (2002) The slope reinforcement by use of FRP. In: Korean geotechnical society national conference, committee of slope stability, November 17, Seoul, pp 155-180

10. Midas IT (2015) MIDAS GTX-NX analysis reference book. Seoul, Korea

11. Kim JS, Lee SD (1999) A study on the failure behavior of the reinforced earth wall structures according to the deformed types of the face. J Korean Geotech Soc 15(4):167-173

12. Lee SD (2014) Soil test principal and method-principles and methods, 2nd edn. Saeron Publication, Suwon, pp $7-289$

Submit your manuscript to a SpringerOpen ${ }^{\circ}$ journal and benefit from:

- Convenient online submission

- Rigorous peer review

- Open access: articles freely available online

- High visibility within the field

- Retaining the copyright to your article

Submit your next manuscript at $\mathbf{s p r i n g e r o p e n . c o m ~}$ 